\title{
Response of Planted South Florida Slash Pine to Simulated Cattle Damage
}

\section{RALPH H. HUGHES}

Highlight: Seedling outplants injured to resemble damage by cattle the 6 th, $18 \mathrm{th}$, or 30 th month after planting were observed until trees attained sapling size. Simulated browsing alone killed few trees, but combinations of damage increased losses and aggravated the stunting of trees. With factorial combinations which included varying degrees of defoliation, shoot removal, and stem breakage, plots with unclipped trees contained $1 \frac{1}{2}$ to 4 times more basal area at the end of the study than trees that were totally defoliated. Without the other treatments, less than a full girdle of the stem was not detrimental.

Cattle rarely graze pine foliage when other green forage is available, but some trampling and browsing damage can always be expected if grazing is permitted the first few years after an area has been planted or seeded (Cassady et al., 1955). Cattle damage seedlings in a variety of ways (Hughes, 1965). They may actually eat the needles, new shoots, or buds, and their hoofs may girdle, bruise, or break the stem.

The findings reported here evolved from attempts to isolatc and measure response to several commonly observed kinds of cattle damage. Results are based on survival and growth

The author was formerly range scientist, Southeastern Forest Experiment Station, U.S. Department of Agriculture, Forest Service, Lehigh Acres, Florida. The research reported was a cooperative study by: the Southeastern Forest Experiment Station, Forest Service, U.S. Dep. Agr.; the Babcock Florida Company; and the Florida Division of Forestry.

Manuscript received May 19,1975 . following the hand application of simulated cattle injury to individual trees.

\section{Methods}

Plantations were established at the Caloosa Experimental Range near Fort Myers, in southwest Florida, on a site typical of the cutover pine flatwoods. Soils were predominately Myakka fine sand, heavy substratum, a common flatwoods soil with strongly acid fine sand underlain by an organic stained pan and clayey substratum. South Florida slash pine (Pinus elliottii var. densa Little \& Dorman) seedlings were planted at a spacing of $5 \times 10 \mathrm{ft}$ on disked ridges constructed with a tractor and fireplow unit.

Five trees in a row comprised a treatment plot. Treatments consisted of various degrees and combinations of foliage removal, shoot removal, stem bending, and girdling, and were applied as soon as needles were fully developed, in May or June. Measurements on growth and survival were taken annually during the dormant winter period, usually in November or December.

The study consisted of 513 plots involving 19 damage treatments, 3 years of planting $(1963,1964$, and 1965) and 3 ages of trees $(6,18$, and 30 months). For data collection and analysis, the three scedling ages were treated as separate tests. Treatments were applied only once, in a randomized block design, and measurements were continued until trees were 5 to $8 \mathrm{ft}$ tall.

Defoliation was accomplished by clipping the ends of the needles with shears to remove an ocularly estimated average 
needle length in percentages as follows: $\mathrm{D}_{\mathrm{O}}=$ no needles clipped; $D_{1}=25 \% ; D_{2}=50 \% ; D_{3}=75 \%$; and $D_{4}=100 \%$.

Shoots, referring to an elongating bud or the current internode formed when elongation is complete, were removed by pinching off the current growth. Treatments were $S_{o}=$ no shoots removed and $S_{1}=$ all shoots removed.

Bending the stem over at a right angle to simulate stem damage by the hoof of a cow was compared with an undisturbed stem, as follows: $B_{0}=$ stem not bent and $B_{1}=$ stem bent $90^{\circ}$.

Girdling was accomplished by removing the bark and cambium from the stem in a 1 -inch band near the groundline. A sharp knife was used to cut radially to wood and slip off the specified portion. Care was taken to avoid leaving strips of inner bark or cambium and to avoid cutting the wood. Girdling was applied as a percentage of stem circumference removed $\left(\mathrm{G}_{\mathrm{o}}=\right.$ no girdle $; \mathrm{G}_{1}=25 \% ; \mathrm{G}_{2}=50 \% ; \mathrm{G}_{3}=75 \%$; and $\mathrm{G}_{4}=100 \%$ ).

There were 19 treatments and combinations, as follows:
1. $\mathrm{D}_{\mathrm{O}} \mathrm{S}_{\mathrm{o}} \mathrm{B}_{\mathrm{o}}$
2. $\mathrm{D}_{\mathrm{o}} \mathrm{S}_{1} \mathrm{~B}_{\mathrm{O}}$
8. $\mathrm{D}_{2} \mathrm{~S}_{\mathrm{O}} \mathrm{B}_{1}$
9. $\mathrm{D}_{2} \mathrm{~S}_{1} \mathrm{~B}_{1}$
15. $\mathrm{G}_{\mathrm{O}}$
3. $\mathrm{D}_{\mathrm{o}} \mathrm{S}_{\mathrm{O}} \mathrm{B}_{1}$
10. $D_{3} S_{o} B_{0}$
11. $\mathrm{D}_{4} \mathrm{~S}_{\mathrm{O}} \mathrm{B}_{\mathrm{o}}$
12. $\mathrm{D}_{4} \mathrm{~S}_{1} \mathrm{~B}_{\mathrm{O}}$
13. $\mathrm{D}_{4} \mathrm{~S}_{0} \mathrm{~B}_{1}$
. $\mathrm{D}_{1} \mathrm{~S}_{\mathrm{O}} \mathrm{B}_{\mathrm{O}}$
14. $\mathrm{D}_{4} \mathrm{~S}_{1} \mathrm{~B}_{1}$
16. $\mathrm{G}_{1}$
17. $\mathrm{G}_{2}$
18. $\mathrm{G}_{3}$
19. $\mathrm{G}_{4}$
7. $\mathrm{D}_{2} \mathrm{~S}_{1} \mathrm{~B}_{\mathrm{o}}$

Results were analyzed as three separate experiments: treatments $1,2,3, \ldots 14$ having to do with mechanical injury combinations; treatments $1,5,6,10$, and 11 on defoliation alone; and treatments $15,16, \ldots 19$ on girdling. Results are presented in separate sections which follow under Results and Conclusions.

Seedling mortality hindered establishment and progress of the study. Enough trees survived to complete the observations on two replications of trees treated at 6 months after planting and all three replications for trees treated at 18 or 30 months. Unless otherwise indicated, the summaries that follow refer to status of trees 6 years after planting.

Only healthy and fully established seedlings were treated, yet survival in final tallies averaged less than $75 \%$. Of 378 plots in the study of defoliation, shoot removal, and stem breakage, all five trees had died in 19 plots by time of final measurement.

In preparing the data for analysis, measurements on five or fewer living trees per plot were averaged for determining annual height growth. Total tree basal area per plot based on diameter at breast height (dbh) was used as an index for comparative productivity. Missing plots were represented by zeros, admittedly an introduction of bias favoring plots with living trees. More often than not, however, year of planting was not a significant variable, and the average measurement of the total 15 or fewer living trees representing trees planted in 1963,1964 , and 1965 was used as the observation for analysis of variance. Because of the small number of trees in each treatment, mortality of seedlings was analyzed by Chi-square. Response to the five defoliation treatments alone was analyzed separately by regression.

Records of annual rainfall helped to explain some of the variation in survival and growth from year to year. Amounts recorded by the Fort Myers Weather Station for the years of planting were 42.90 inches in $1963,32.83$ in 1964 , and 50.83 inches in 1965.

\section{Results and Conclusions}

\section{Defoliation Alone \\ Survival}

When not combined with shoot removal or stem breakage, total defoliation when applied 6 months after planting appeared detrimental, and 50\% defoliation applied at 12 months seemed to improve survival. Average survival for trees treated at 6,18 , or 30 months after planting was 67,66 , and $85 \%$, respectively.

\section{Annual Height Growth}

Losses in growth tended to be recovered as trees grew older. By the end of the study, only the trees treated at 6 months after planting showed a significant response to defoliation (Fig. 1). Growth of these trees declined consistently with increasing intensity of defoliation. Precision, however, was not nearly as good as desired.

Coefficients of determination indicated that only one-fourth of the variation in growth was associated with

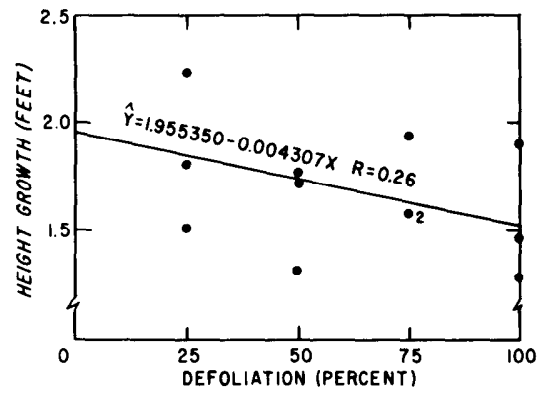

Fig. 1. Relationship between annual height growth of trees and percent defoliation 6 months after planting. (Trees were measured at age 6 years after planting.) • = data points.

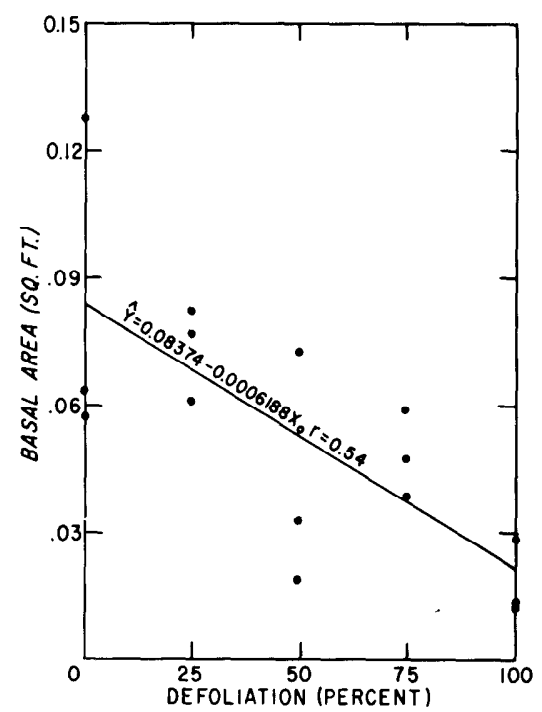

Fig. 2. Relationship between basal area of trees per plot and percent defoliation at age 6 months after planting. (Trees were measured at age 6 years after planting.) • $=$ data points.

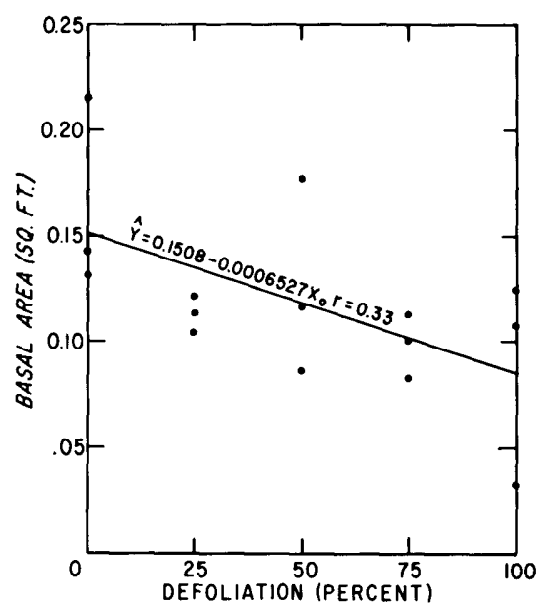

Fig. 3. Relationship between basal area of trees per plot and percent defoliation at age 18 months after planting. (Trees were measured at age 6 years after planting.) • $=$ data point $\mathrm{s}$. 
defoliation. Sensitivity to defoliation usually declined with age at time of treatment.

\section{Basal Area Per Plot}

Defoliation had a significant effect on basal area when applied at 6 or 18 months after planting (Figs. 2 and 3) but not when applied at 30 months. Volume per plot declined as intensity of defoliation increased.

Coefficients of determination indicated that $1 / 3$ or $1 / 2$ of the variation in volume was associated with defoliation for trees treated at ages 6 or 18 months, but only $6 \%$ for trees treated at 30 months.

\section{Mechanical Injury Combinations}

Survival

When combined with shoot removal and stem bending, total defoliation was always detrimental (Table 1). When applied 6 months after planting, most of the other treatments tested which involved 50 or $100 \%$ defoliation also were harmful. Survival varied considerably among trees treated 18 or 30 months after planting, and there was no definite trend of treatment effects.

Table 1. Effects of mechanical injury combinations on survival (\%).

\begin{tabular}{|c|c|c|c|c|c|}
\hline \multicolumn{3}{|c|}{ Kind of injury } & \multirow{2}{*}{\multicolumn{3}{|c|}{$\begin{array}{c}\text { Age treated } \\
\text { (months after planting) }\end{array}$}} \\
\hline \multirow{2}{*}{$\begin{array}{c}\text { Defoliation } \\
(\%)\end{array}$} & \multirow{2}{*}{$\begin{array}{l}\text { Shoots } \\
\text { removed }\end{array}$} & \multirow{2}{*}{$\begin{array}{l}\text { Stem } \\
\text { bent }\end{array}$} & & & \\
\hline & & & 6 & 18 & 30 \\
\hline 0 & No & No & 72 & 60 & 88 \\
\hline 0 & Yes & No & 72 & 60 & $75^{*}$ \\
\hline 0 & No & Yes & 65 & 69 & $65 * *$ \\
\hline 0 & Yes & Yes & 60 & 67 & 78 \\
\hline 50 & Yes & No & 68 & 73 & 80 \\
\hline 50 & No & Yes & $58 *$ & 60 & $75^{*}$ \\
\hline 50 & Yes & Yes & $48 * *$ & 51 & $75 *$ \\
\hline 100 & Yes & No & $48 * *$ & 53 & 80 \\
\hline 100 & No & Yes & $32 * *$ & 47 & $62 * *$ \\
\hline 100 & Yes & Yes & $30 * *$ & $20 * *$ & $60 * *$ \\
\hline
\end{tabular}

$* P=.05$.

$* * P=.01$.

\section{Annual Height Growth}

Defoliation continued to limit growth from year to year, whereas those trees which survived the initial shock of shoot removal or stem breakage generally grew reasonably well without obvious stunting. Trees defoliated at 6 months of age were not as tall at the end of the first year as prior to defoliation midway the same year. By the fifth year after treatment, reductions in annual growth compared with no defoliation were about $20 \%$ for trees with needles clipped to half their length at 6 months after planting and $40 \%$ with total defoliation. Similar reductions were noted for trees treated 18 months after planting when measured the second, third, and fourth year after treatment. Growth data for trees treated 30 months after planting were inconclusive.

\section{Basal Area Per Plot}

Total defoliation was detrimental whether applied 6,18 , or 30 months after planting. Unclipped trees contained $1 \frac{1}{2}$ to 4 times more basal area per plot than trees totally defoliated (Table 2). With 50\% defoliation, volumes averaged with shoot removal and stem breakage tended to be between these extremes.

Stem breakage was similarly detrimental to the three ages of trees tested. Plots occupied by trees without stem damage
Table 2. Basal area $\left(\mathrm{ft}^{2}\right)$ per plot as influenced by foliage removal (\%) $(3 \times 2 \times 2$ factorial $) .^{1}$

\begin{tabular}{cccc}
\hline & \multicolumn{3}{c}{ Age after planting when treated } \\
\cline { 2 - 4 } Defoliation & 6 months & 18 months & 30 months \\
\hline 0 & $0.0267 \mathrm{a}$ & $0.0684 \mathrm{a}$ & $0.0837 \mathrm{a}$ \\
50 & $0.0195 \mathrm{a}$ & $0.0600 \mathrm{a}$ & $0.0772 \mathrm{ab}$ \\
100 & $0.0065 \mathrm{~b}$ & $0.0321 \mathrm{~b}$ & $0.0611 \mathrm{~b}$ \\
\hline Talues within a column having the same letters do not differ signifi- \\
cantly at the 5\% level according to Duncan's multiple range test. All \\
comparisons are made vertically.
\end{tabular}

contained $1 \frac{1}{2}$ to twice more basal area than damaged trees, as indicated by the following tabulation:

\begin{tabular}{lccc} 
& \multicolumn{3}{c}{ Age of trees at time of treatment } \\
\cline { 2 - 4 } Stem position & $\begin{array}{c}6 \text { months } \\
\left(\mathrm{ft}^{2}\right)\end{array}$ & $\begin{array}{c}18 \text { months } \\
\left(\mathrm{ft}^{2}\right)\end{array}$ & $\begin{array}{c}30 \text { months } \\
\left(\mathrm{ft}^{2}\right)\end{array}$ \\
Normal-not bent & 0.0234 & 0.0617 & 0.0821 \\
Horizontal-bent $90^{\circ}$ & 0.0117 & 0.0453 & 0.0659
\end{tabular}

In no case did shoot removal have a significant effect on basal area.

For trees treated at 30 months, basal area per plot appeared related to annual rainfall, with best volume occurring with near-normal rainfall in 1965 and least basal area with the least rainfall in 1964.

\section{Girdling}

\section{Survival}

Full girdles were followed by losses of more than $1 / 2$ of trees the first year and $3 / 4$ or more by the end of the study. Less than a full girdle killed very few trees, with survivals about the same for $1 / 4,1 / 2$, or $3 / 4$ girdles.

\section{Annual Height Growth}

Full girdles were always detrimental, the sharp decrease in annual growth beginning immediately and continuing through subsequent annual remeasurements. Annual growth of trees with full girdles was usually less than half that of other trees. Responses varied little when less than a full girdle was inflicted. A $3 / 4$ girdle, for example, was generally no better or no worse than a $1 / 4$ girdle.

\section{Basal Area Per Plot}

Measurements required to determine basal area were not available for this phase of the study.

\section{Discussion}

Although several treatments were not representative of the damage that commonly occurs when cattle graze young plantations, response to a specific type and degree of injury in terms of survival and eventual growth may be reasonably concluded from these studies. The results agree fairly well with observations obtained from much field experience on specific types of cattle damage and special effort over a period of years to obtain evidence of the effects of cattle damage.

Enough kinds of injury were selected and ages of trees treated to provide a balanced experimental design that would bridge widely varying intensities of combinations of types of injury. Some of the treatments were assumed to be unusually severe, as for example, total defoliation and full girdling. Bending the stem over at right angles to simulate stem breakage by the hoof of a cow is a type of damage which occurs most frequently during the first year after planting; 
